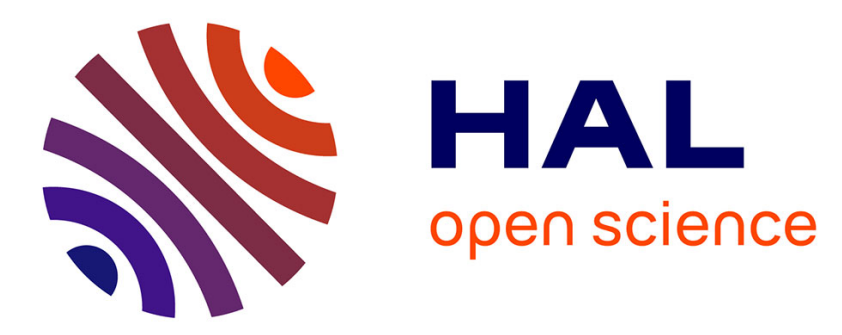

\title{
The heterogeneous cyclicality of income and wages among the distribution
}

María Cervini-Plá, Antonia López-Villavicencio, José Ignacio Silva

\section{To cite this version:}

María Cervini-Plá, Antonia López-Villavicencio, José Ignacio Silva. The heterogeneous cyclicality of income and wages among the distribution. 2015. halshs-01133823

\section{HAL Id: halshs-01133823 \\ https://shs.hal.science/halshs-01133823}

Preprint submitted on 20 Mar 2015

HAL is a multi-disciplinary open access archive for the deposit and dissemination of scientific research documents, whether they are published or not. The documents may come from teaching and research institutions in France or abroad, or from public or private research centers.
L'archive ouverte pluridisciplinaire HAL, est destinée au dépôt et à la diffusion de documents scientifiques de niveau recherche, publiés ou non, émanant des établissements d'enseignement et de recherche français ou étrangers, des laboratoires publics ou privés. 


\title{
GATE

UMR 5824

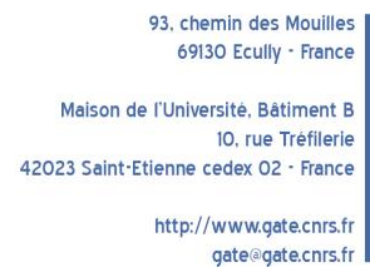

WP 1506 - March 2015

\section{The heterogeneous cyclicality of income and wages among the distribution}

María Cervini-Plá, Antonia López-Villavicencio, José I. Silva

\begin{abstract}
:
We investigate the cyclicality of real wages and income using individual data for the UK over the 1991-2008 period. By paying special attention to the heterogeneity among different earnings and income groups, we document that individuals at the top of the distribution are more cyclical than lower ones. Moreover, the estimated cyclicality is considerably higher in recessions than in expansions for top-incomes. We also show that real wages and income are roughly acyclical for low wage and income workers. Instead, their adjustment to the cycle takes place through transitions to and from unemployment.
\end{abstract}

\section{Keywords:}

Real wage, cyclicality, heterogeneity, income distribution JEL codes:

E24, E32, J31

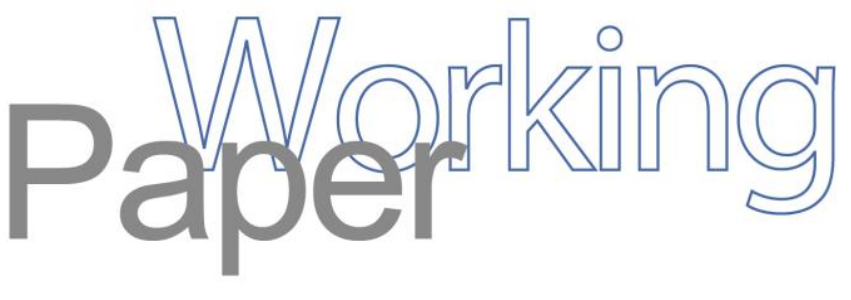




\title{
The heterogeneous cyclicality of income and wages among the distribution
}

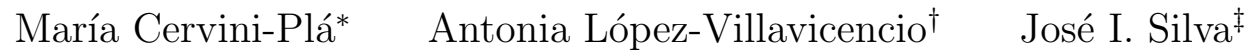

March 18, 2015

\begin{abstract}
We investigate the cyclicality of real wages and income using individual data for the UK over the 1991-2008 period. By paying special attention to the heterogeneity among different earnings and income groups, we document that individuals at the top of the distribution are more cyclical than lower ones. Moreover, the estimated cyclicality is considerably higher in recessions than in expansions for top-incomes. We also show that real wages and income are roughly acyclical for low wage and income workers. Instead, their adjustment to the cycle takes place through transitions to and from unemployment.
\end{abstract}

JEL Classification: E24, E32, J31.

Keywords: real wage, cyclicality, heterogeneity, income distribution

*EQUALITAS, Spain. E-mail:mariacervinipla@gmail.com.

${ }^{\dagger}$ Université de Lyon, Lyon, F-69007, France; CNRS, GATE Lyon Saint-Etienne, Ecully, F-69130, France and Université Lyon 2, Lyon, F-69007, France. E-mail:lopez@gate.cnrs.fr.

${ }^{\ddagger}$ Corresponding author. Universitat de Girona and University of Kent, Campus de Montilivi, 17071, Girona. E-mail: jose.silva@udg.edu, phone: +34972418779. 


\section{Introduction}

Documenting and assessing real wage cyclicality (RWC) has been a central focus in economics for a very long time. However, even if a large number of micro studies find that wages change in a procyclical way, wage cyclicality is found to differ between alternative wage measures, demographic and personal characteristics as well as between job stayers and employees who change their job. For instance, Mitchell, Wallace, and Warner (1985) find heterogeneous behaviour among demographic groups that are differentiated by age, sex and race. In turn, Bils (1985) analyses differences between blacks and whites, while Hart (2006) find differences by gender. In addition, Bils (1985), Solon, Barsky, and Parker (1994), Devereux and Hart (2006), Hart (2006) or Shin and Solon (2007) provide evidence of different cyclicality among individuals who are moving between employers or in and out of the work force.

Although some previous studies outline the importance of controlling for composition bias, the fact that wage cyclicality may differ among workers throughout the earnings or/and income distribution has not received enough attention in the literature. In this paper, we propose that cyclicality can be a heterogeneous parameter depending on both the changes in the composition of the labour force and different behaviour in the real wages of each percentile. Although Mitchell, Wallace and Warner (1985) mention that differences in the employment behaviour of low and high wage earners can affect the composition of the labour force, and therefore, the cyclical behaviour of aggregate wages, they do not provide empirical evidence to back up this hypothesis. The only exception is Swanson (2007), who uses the US Panel Study of Income Dynamics, finding that although real wages are procyclical across the entire distribution of workers, the wages of those in lower-income groups exhibited greater procyclicality. We add to this literature by testing whether, even for a given labour force composition, the relationship between real wages and the business cycle can be different among groups. In particular, we are interested in the heterogeneity that arises across the UK among high- and low-wage/income workers. Moreover, we also study the presence of asymmetries in the response of income and wages during times of economic expansion and recession.

We explore this source of heterogeneity by using wave 1 to 18 of the British Household Panel Survey (BHPS). Our analysis is motivated by the fact that, for many years, the predominant part of the literature was based on the idea that the 
incomes of low-income households were more cyclical than those at the top of the income scale. The common explanation was that unemployment has the greatest impact on low-wage workers, thereby affecting their income (Clark and Summers (1981), Kydland (1984)). However, there is recent literature that suggest the opposite effect. These topical studies suggest that during the past quarter of a century, the incomes of high-income households have become much more sensitive to aggregate fluctuations than was previously the case. For instance, Parker and VissingJorgensen (2010) document that the incomes of households in the top 1 percent have become more than twice as sensitive to aggregate income fluctuations as the income of the average household in the United States and Canada.

In addition, Swanson (2007), Parker and Vissing-Jorgensen (2010) or Piketty and Saez (2012) suggest that the evolution of top incomes is not exclusively due to capital or entrepreneurial income. In fact, given that wages and salaries represent the main share of total income, it follows that wages are also a major source of the change in cyclicality of top incomes. ${ }^{1}$ This literature, however, disregards low-income individuals, and therefore, does not adequately address the relationship between the business cycle and the entire income distribution.

We go beyond the previous literature by analysing how the business cycle affects income and wages at different points in the distribution. This allows us to report the differences between the bottom and the top wage and income groups. Moreover, our database avoids some drawbacks of the previous studies. First, contrary to Parker and Vissing-Jorgensen (2010), our unit of observation is an individual and not a tax unit. This is an important advantage because the steady downward trend in the number of individuals per tax unit over time implies that relying on these units possess a problem for measuring trends if this ratio changes unevenly across income groups. Second, instead of working with repeated cross sections, we rely on a panel of observations. As such, we are able to track changes for a constant population of individuals and not for groups of households that overlap but are not completely identical over the years.

We demonstrate that there is a type of heterogeneity that has been largely ig-

\footnotetext{
${ }^{1}$ Based on data for the US, Parker and Vissing-Jorgensen (2010) show that the income cyclicality of households in the top 1 percent is roughly similar if one leaves out households with stock options. Similarly, Piketty and Saez (2012) propose that in 2007, one needs to enter into the top $0.1 \%$ for capital income to dominate wage income. Moreover, if one takes away capital gains, then wage income dominates capital income at the very top.
} 
nored in micro-oriented studies. Indeed, our results show that income and wages are procyclical. Nonetheless, we show that this cyclicality differs across groups. In particular, cyclicality is stronger for workers who are at the top of the wage and income distribution. Yet moving to the lower tail of the distribution reveals acyclical income and wages. We also provide evidence that wage cyclicality are not the same during economic expansions and recessions. Indeed, whereas income of top-income individuals is roughly the same in expansions and contractions, wages react stronger during recessions. However, the income and wages of low-income individuals are roughly acyclical both during times of expansion and during recessions. We reconcile our findings by showing that an important portion of the acyclicality for low income individuals is due to the loss of jobs. Another possible explanation for this acyclical income and wages is the role that benefits play in these individuals' total income.

This paper is organised as follows. Section 2 presents the empirical methodology. Section 3 explains the dataset used. Section 4 presents the results and Section 5 concludes.

\section{Empirical framework}

The starting point of our empirical strategy consists of analysing the cyclical exposure of the different wage and income groups. We follow the literature on wage cyclicality and regress, for each wage or income percentile, the (log) real wages or income $(x)$ for the $i^{\text {th }}$ worker in year $t$ in the whole sample and by groups as follows:

$$
\ln x_{i t}=\alpha_{t}+\delta_{1}^{\prime} Z_{i}+\delta_{2} A_{i t}+\delta_{3} A_{i t}^{2}+\epsilon_{i t}
$$

where $\alpha_{t}$ is the time-variant coefficient (the time-effect), $Z$ is a vector of timeinvariant worker characteristics such as race, gender, years of education, ability, and motivation; $A$ is the worker's age as of year $t$ and $\epsilon_{i t}$ is the transitory worker-specific error term. Following Solon, Whatley, and Stevens (1997), we control for both the observable and unobservable elements of $Z$ by taking the first-difference in Equation (1):

$$
\Delta \ln x_{i t}=\Delta \alpha_{t}+\beta^{\prime} Z_{i t}+\Delta \epsilon_{i t}
$$

where the vector $Z$ contains the worker's age. To characterise the cyclicality of the year's effects on real wages we write the time-variant coefficient as follows: 


$$
\alpha_{t}=\gamma_{1}+\gamma_{2} t+\gamma_{3} t^{2}+\gamma_{y} \ln Y_{t}+v_{t}
$$

where $t$ is a linear time trend, $Y_{t}$ is the GDP in year $t$ and $v_{t}$ is the error term. The quadratic in time is included to account for secular trends. Taking the first difference of Eq. (3) and substituting in Equation (2) yields:

$$
\Delta \ln x_{i t}=\gamma_{2}+2 \gamma_{3} t+\gamma_{y} \Delta \ln Y_{t}+\beta^{\prime} Z_{i t}+\left(\Delta \epsilon_{i t}+\Delta v_{t}\right)
$$

Equation (4) represents the standard wage cyclicality relationship where $\gamma_{y}$ captures the cyclical elasticity of income or real wage's with respect to GDP growth. Alternatively to the GDP growth, we used the output gap $\left(y-y_{t}^{*}\right)$ as an indicator of the business cycle. This measurement allows us to differentiate between economic expansions and recessions with enough observations in both regimes. ${ }^{2}$

As noticed by Solon, Whatley, and Stevens (1997), one way to estimate the cyclical elasticity is to apply ordinary least squares (OLS) to equation (4). However, if the error terms of different workers in the same percentile are cross-sectionally correlated, the associated standard error of the OLS estimates would be biased. We treat the cross-sectional correlation of the error term in equation (4) by applying generalised least squares (GLS) to Eq. (4), which provides efficient coefficient estimates and consistent standard error estimates. ${ }^{3}$

\section{$3 \quad$ Data and descriptive statistics}

Our analysis is based on waves 1 to 18 (years 1991-2008) of the British Household Panel Survey (BHPS). The BHPS is a nationally representative sample consisting of around 5,500 households throughout Great Britain. The panel starts in 1991 with 13,840 individuals being interviewed. The same individuals were followed, as far as possible, for the subsequent waves of the survey. ${ }^{4}$

\footnotetext{
${ }^{2}$ In the case where the growth rates of time series of interest are predominantly positive (negative), this may result in a situation where the number of effective observations in the negative (positive) regime is insufficient for the OLS estimator to be well determined.

${ }^{3}$ Note that it is also possible to use a two-stage procedure, which is a close substitute for singlestage GLS. However, the two-stage procedure can yield serially correlated or heteroskedastic error terms. See Solon, Whatley, and Stevens (1997) for a discussion.

${ }^{4}$ The BHPS data is available from the Data Archive at Essex University.
} 
Even though the British Household Panel Survey (BHPS) covers only the 19912008 period and the sample is relatively small compared with the Annual Survey of Hours and Earnings (ASHE), our decision to carry out our analysis on this source is based on several points. The first one is that we work with income groups. Indeed, the BHPS covers a stratified random cluster sample of households and provides information on hourly wage and annual income. Moreover, based on this information, we are able to decompose income into labour income (pay from current and previous job), pensions (receipts from non-state pension sources), benefits (all receipts from state benefits such as retirement pensions and unemployment benefits), transfers (educational grants, sickness insurance, etc) and interest (income from savings and investments, and all receipts from rent from property or boarders and lodgers). ${ }^{5}$ Second, the BHPS provides high quality data at an individual and household level for labour markets. Therefore, we are able to capture switches from employment to unemployment as well as reductions in the hours worked by workers who remain in the labour force.

Moreover, as noticed by Stewart and Swaffield (2002), although the BHPS cannot compete with the New Earnings Survey (The ASHE replaced the New Earnings Survey in 2004) or the Labour Force Survey (LFS) in terms of sample size, the BHPS has advantages over these sources in the context of the measurement of hourly pay. First, the BHPS does not have the problem of a large number of proxy responses that the LFS suffers from. Second, interviewers check respondents' pay slips wherever possible. Third, the BHPS does not suffer from the potentially serious sample selection bias that exists in the NES, with workers earning below the pay-as-youearn tax threshold, who have an above average probability of low hourly pay, being under-represented in the sample. In the BHPS, regular questions asked in all waves of the survey lead to hourly pay being constructed in a very similar way to that used on the LFS. This is the individual's usual weekly gross earnings (or gross earnings converted to a weekly basis) divided by total paid hours (basic pay plus paid overtime) worked in a normal week.

Our sample is restricted to males heads of household between 21 and 60 years old. We use this restricted sample to avoid several mis-specification issues. First, we restrict our sample only to males in order to mitigate issues of endogenous female

\footnotetext{
${ }^{5}$ Even though the ASHE database considers a longer time-period, and provides very wellmeasured wages and large enough samples, it does not contain information on income. Moreover, it covers employees only. Non employment appears as absence from the data for that year.
} 
labour market participation. Second, individuals are allowed to enter the panel at any wave and to re-enter the panel if they exit in previous waves. Such a sample selection produces an unbalanced panel since not all individuals are present for all eighteen waves. Movements into and out of the sample may be due to unemployment, retirement and attrition. An individual has to be present in the sample for at least two consecutive years in order to be considered in our sample since we work with the first difference of real income and real wage. Third, our chosen age range excludes the extremes of the earnings life cycle, where volatility arising just after labour market entry or before retirement may be confounded with volatility due to structural labour market changes. ${ }^{6}$

The main dependent variables are the logarithmic change between two consecutive waves in total income and the logarithmic change between two consecutive waves in the average gross hourly wage, both variables are deflected by the aggregate consumer price index. Hourly wages are calculated as follows:

$$
h w=p a y g u /(j b h r s \times 4.3)
$$

where paygu is the usual gross pay per month in the current job, and jbhrs is the number of hours normally worked per week. ${ }^{7}$ We then compute the first difference of the log of the real hourly wage, which corresponds to:

$$
r h w=(h w / c p i) \times 100
$$

where $c p i$ is the consumer price index.

The key explanatory variables are the change in gross domestic product and the output gap, which are intended to reflect movements in the business cycle. We calculate the first variable as the change in the log in GDP from year $t$ to year $t-1$.

\footnotetext{
${ }^{6}$ We started with a sample of 115,616 individual year observations. We dropped women from this sample, which represent the $52.6 \%$ of the total observations. From the 54,849 remaining men, we chose only the $74.5 \%$ heads of family (i.e. we kept 40,885 observations). We then eliminated male heads of family younger than 21 and older than 60 years old. This left us with 38,412 (93.9\% of the previous sample).

${ }^{7}$ That is, monthly wages are divided by the number of hours worked per week multiplied by the number of weeks per month (4.3 on average). This is a current way to compute real hourly wages in the literature (see Stewart and Swaffield (2002) or Rabe (2011)). We do this for those who work between 10 and 60 hours per week.
} 
In order to estimate the income and wage cyclicality for different groups, we calculate the percentile in which the individual is placed on the entire distribution of either wage or income in each wave and consider the percentile to which the individual belongs at time $t$. High-wage/income individuals are defined to be those in the top percentile, and low-wage/income individuals those in the bottom percentile. We drop the observations placed at the lowest and higher $1 \%$ in the distribution in order to avoid the extremes of the distribution that are usually reported with more errors. ${ }^{8}$

We also analyse the cyclicality of hours worked for the different groups. The hypothesis behind this exercise is that the adjustment in the labour market might be through changes in the hours worked rather than due to reductions in wages at the bottom of the distribution. In this case, we work with two samples. In the first case, we use the same sample used to study wage cyclicality (i.e. the intensive margin). However, in the second case we extend the sample to all men in the restricted age group that ever worked (extensive margin). This allows us to capture movements from and to unemployment by constructing a balanced panel with 0 hours in the case an individual is unemployed.

Tables 1 and 2 show some descriptive statistics of important characteristics by income group: i) the percentage of workers with temporary contracts are higher among low income groups which are also younger and with a lower level of education than workers at the top of the distribution and ii) wages remain close to the minimum established real wage in the UK for the bottom income group. ${ }^{9}$ Indeed, about 8 percent of low income individuals have temporary contracts, compared to just $3 \%$ for the top income. This suggests that low paid workers are easier to fire. Moreover, according to our data, there is evidence of non-compliance regarding the minimum wage, with the real hourly wage for the lowest-paid workers remaining very close to the minimum wage. In particular, the mean of the real hourly wage for the bottom $10 \%$ reached 6.3 pounds in 2008, almost equal to the established minimum wage (6.2). Yet 6.3 pounds is the mean wage, which implies that many individuals in this group receive wages below the minimum wage. At first glance, this non-compliance evidences that there is little or no scope for variation in wage adjustments in bad labour market conditions for this type of workers. ${ }^{10}$

\footnotetext{
${ }^{8}$ By removing the poorest and the richest $1 \%$ we end up with a sample of 37,647 observations.

${ }^{9}$ To save space, we do not present the statistics according to wage groups.

${ }^{10}$ The Low Pay Commission Report 2012 provides evidence that $1 \%$ of employees in 2008 were paid less than the national minimum wage in the UK. The evidence of non-compliance is even more striking for jobs paid less than the then forthcoming minimum wage, representing $5.2 \%$ of total
} 
Table 1: Average age, percentage of workers with temporary contract and level of education by income group

\begin{tabular}{l|cccc}
\hline \hline & Lowest & Lowest & Top & Top \\
& $10 \%$ & $25 \%$ & $25 \%$ & $10 \%$ \\
\hline Average age & & & & \\
& $\mathbf{3 5 . 9}$ & $\mathbf{3 7 . 0}$ & $\mathbf{4 1 . 9}$ & $\mathbf{4 2 . 8}$ \\
Workers with Temporary contracts & $\mathbf{7 . 8 2 \%}$ & $\mathbf{5 . 9 0 \%}$ & $\mathbf{3 . 3 4 \%}$ & $\mathbf{3 . 1 8 \%}$ \\
Higher educational qualification & & & & \\
None & & & & \\
Vocational/Technic & $20.3 \%$ & $22.3 \%$ & $4.1 \%$ & $2.8 \%$ \\
GCSE-o level & $5.2 \%$ & $7.3 \%$ & $3.8 \%$ & $2.2 \%$ \\
A-level/higher education below college degree & $30.5 \%$ & $31.2 \%$ & $23.1 \%$ & $18.3 \%$ \\
College/univ degree & $23.3 \%$ & $25.5 \%$ & $37.4 \%$ & $34.4 \%$ \\
\hline \hline
\end{tabular}

employees for the same year. By occupations, around 48 per cent of jobs in the cleaning industry, 47 per cent in hospitality, 37 per cent in hairdressing and 34 per cent in child care were paid less than the minimum wage. 


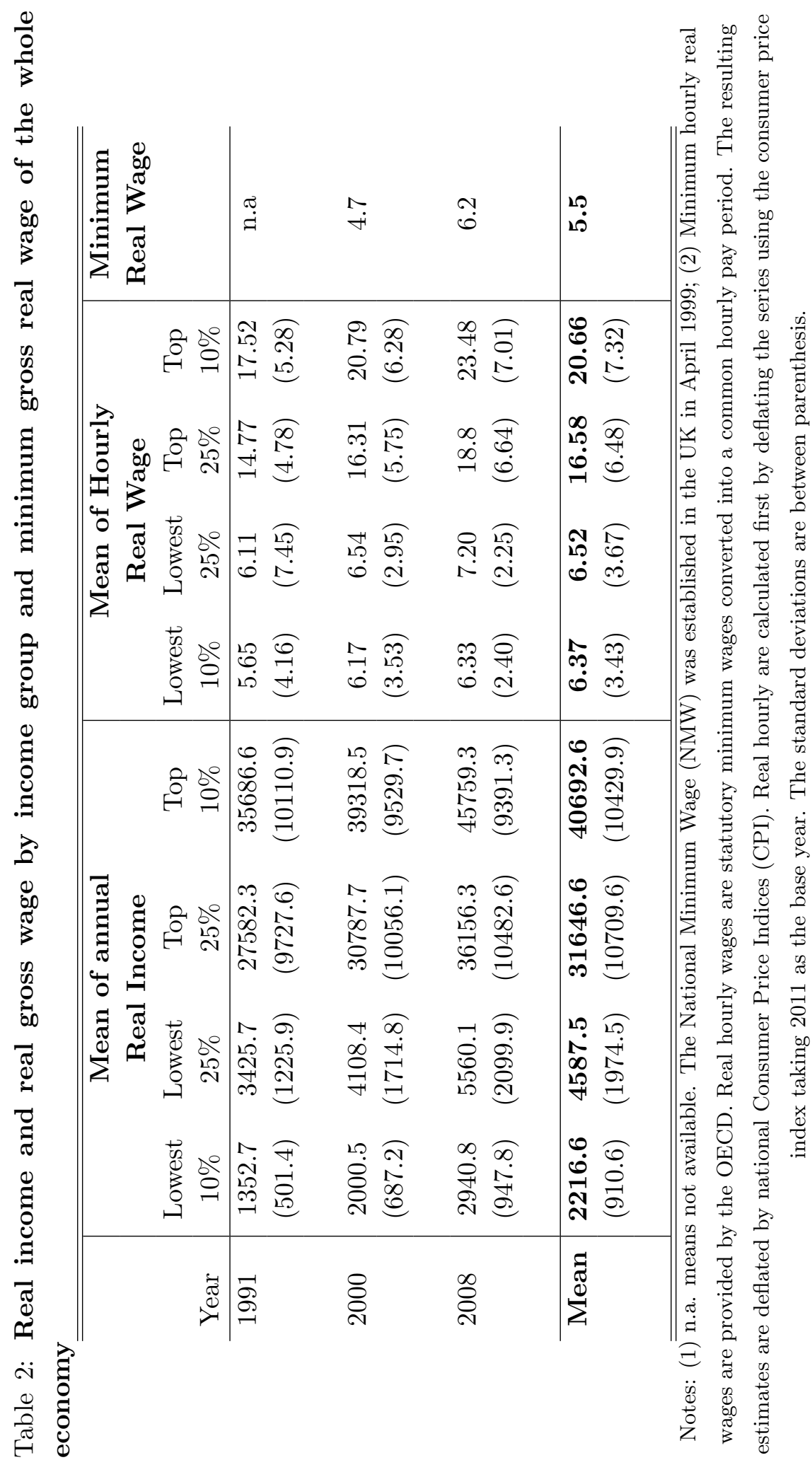


Furthermore, in Table 3 we show the main sources of annual individual income by income group. This table documents two main points. First, benefits account for roughly fifty percent of total income for low income individuals. On the contrary, these sources of income account for only a low share of total income for the top 10 percent, the main source of income being labour income. This implies that a main part of the income of low income individuals is, in principle, counter-cyclical or acyclical. Indeed, while government subsidies (i.e unemployment benefits) tend to be counter-cyclical, social security transfers do not react to the cycle, probably because they include large components, such as health and pension payments that are acyclical and that dominate the cyclical component (Égert (2010)). 


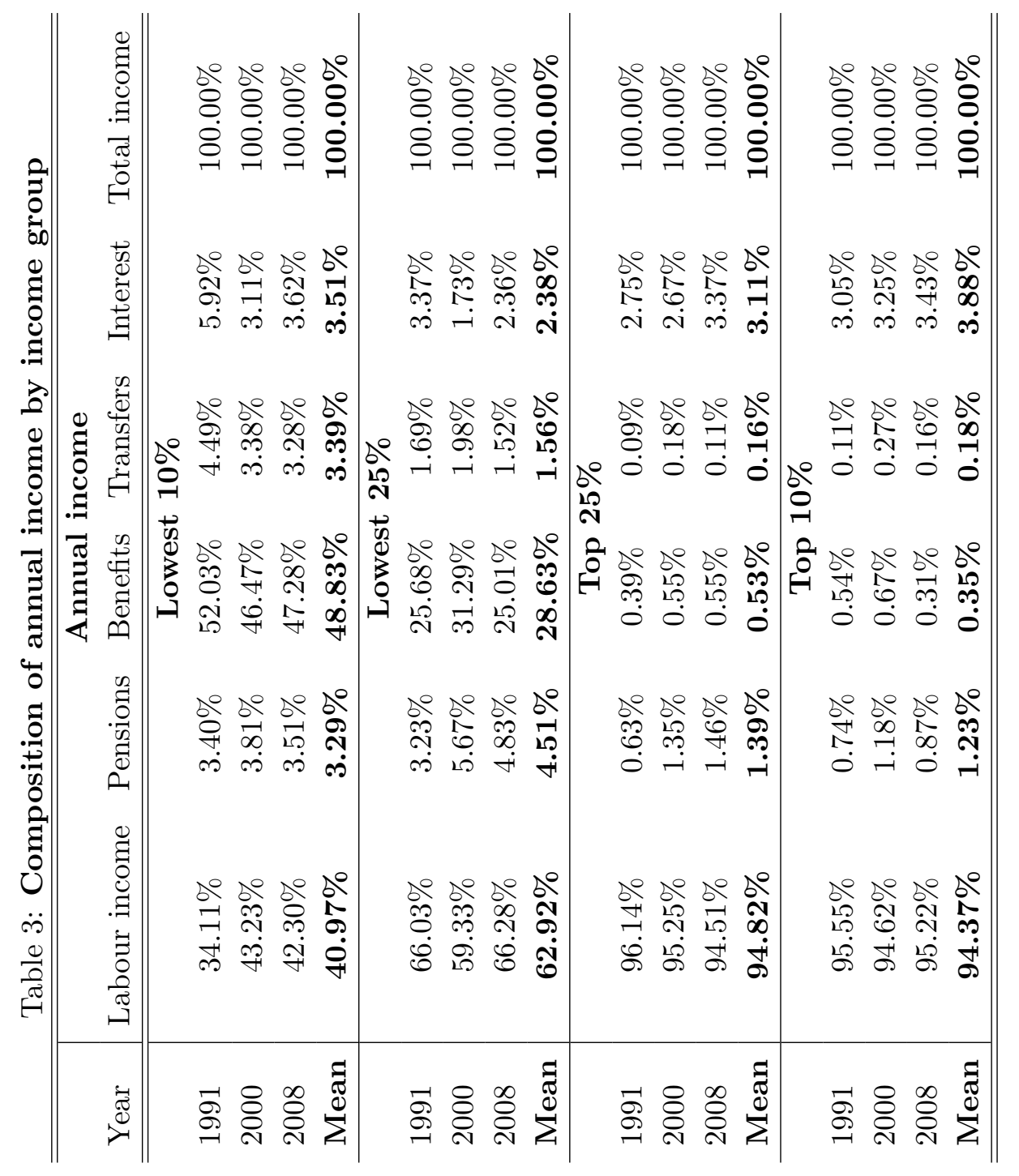


Second, whereas pensions, transfers and benefits have been steadily decreasing as a source of total income for the poorest groups since 1991, labour income is increasing. In contrast, the share of pensions, transfers and interests is increasing slightly for top income individuals.

\section{Results}

The top panel of Table 4 presents our main findings in terms of cyclicality for all the individuals in our sample and for selected groups. In accordance with previous studies based on micro data, the symmetric business cycle variable $\left(\gamma_{y}\right)$ indicates procyclical income and wages. Indeed, a percentage point rise in the GDP is associated with an increase in real income and wages of about $0.6 \%$ and $0.7 \%$, respectively. The results with the output gap confirm this cyclicality for the whole sample.

Our first main contribution is in terms of heterogeneity regarding cyclicality among the different income groups. In this respect, our results show that the real wages and income of the top earner workers -particularly the top $10 \%$ in the income and wage distribution- are much more responsive to the cycle than lower groups. In fact, income and wages of the poorests individuals -the lowest $10 \%$ and $25 \%$ are not influenced by movements in the GDP or the output gap. ${ }^{11}$ Striking though these results are, they remain partly consistent with the limited previous literature. Indeed, Parker and Vissing-Jorgensen (2010) document that, since 1982, the wage and salary income of the top 1 percent in the United States has a cyclicality of 2.4 , and that of the top 0.01 percent a cyclicality of 6.2 , compared with a cyclicality of less than 1 for all tax units. Unfortunately, Parker and Vissing-Jorgensen (2010) do not provide the cyclicality for bottom wage percentiles. We present evidence for the UK -without precedent to the best of our knowledge-that income and earnings of low-income units are roughly acyclical. ${ }^{12}$ The only exception is Swanson (2007), who also considers the entire distribution of wages and shows that the wages of lower-income workers exhibited greater procyclicality in the US. However, he doesn't explore the asymmetric reaction during expansions and recessions.

\footnotetext{
${ }^{11}$ Note that the estimated coefficients for these groups are not significantly different form zero.

${ }^{12}$ Moreover, we performed the same exercise for the whole sample (including all the male heads of households). We then excluded only individuals placed at the lowest and highest $1 \%$ in the income distribution and finally we only excluded individuals in the extremes of the earnings life cycle. Results are presented in Table 7 in the appendix. As seen, the main conclusions are quite similar.
} 
Table 4: Cyclicality of real income and wages by income group

\begin{tabular}{|c|c|c|c|c|c|}
\hline Elasticity & $\begin{array}{c}\text { All } \\
\text { units }\end{array}$ & $\begin{array}{c}\text { Lowest } \\
10 \%\end{array}$ & $\begin{array}{c}\text { Lowest } \\
25 \%\end{array}$ & $\begin{array}{l}\text { Top } \\
25 \%\end{array}$ & $\begin{array}{l}\text { Top } \\
10 \%\end{array}$ \\
\hline \multicolumn{6}{|c|}{ INCOME } \\
\hline$\widehat{\gamma_{y}}$ & $\underset{(2.62)}{\mathbf{0 . 5 9 6}}$ & $\begin{array}{l}0.118 \\
(0.23)\end{array}$ & $\begin{array}{c}0.546 \\
(0.79)\end{array}$ & $\underset{(2.15)}{\mathbf{0 . 6 6 7}}$ & $\underset{(2.12)}{\mathbf{1 . 7 0 0}}$ \\
\hline$\widehat{\gamma_{y-y}} *$ & $\begin{array}{c}\mathbf{2 . 1 2 4} \\
(5.65) \\
\end{array}$ & $\begin{array}{c}1.455 \\
(1.28) \\
\end{array}$ & $\begin{array}{c}2.035 \\
(1.68) \\
\end{array}$ & $\begin{array}{c}\mathbf{2 . 3 1 6} \\
(4.71)\end{array}$ & $\begin{array}{c}\mathbf{2 . 9 2 4} \\
(2.82) \\
\end{array}$ \\
\hline \multicolumn{6}{|c|}{ WAGES } \\
\hline$\widehat{\gamma_{y}}$ & $\underset{(6.00)}{\mathbf{0 . 6 8 4}}$ & $\begin{array}{c}-0.353 \\
(-1.26)\end{array}$ & $\underset{(1.89)}{\mathbf{0 . 4 8 2}}$ & $\underset{(4.04)}{\mathbf{0 . 8 0 5}}$ & $\underset{(4.82)}{\mathbf{1 . 1 6 2}}$ \\
\hline$\widehat{\sqrt{y-y} *}$ & $\underset{(8.88)}{\mathbf{1 . 5 6 2}}$ & $\begin{array}{l}0.027 \\
(-0.06)\end{array}$ & $\underset{(2.48)}{\mathbf{1 . 0 4 1}}$ & $\underset{(5.09)}{\mathbf{1 . 8 1 0}}$ & $\begin{array}{c}\mathbf{2 . 5 9 4} \\
(4.02)\end{array}$ \\
\hline
\end{tabular}

Notes: (1) $\widehat{\gamma_{y}}$ and $\widehat{\overline{\gamma_{y-y} *} \text { are the estimated coefficient for cyclicality according to G }} \mathrm{DP}$ growth and output gap, respectively; (2) $t$-values in parenthesis; (3) Significant coefficients at $10 \%$ significance level are indicated in bold.

So far, we have estimated the global effect of the business cycle. However, these effects might differ during expansions and contractions. For instance, Hines, Hoynes, and Krueger (2002) document that the effects of changes in unemployment rates on earnings are larger in recessions for the United States. Shin and Shin (2008), in turn, provide evidence that real wage cyclicality among job stayers in the United States is mainly explained by large wage adjustments during the period when the unemployment rate reaches a historical minimum level from the start of the employee's current job. More recently, Martins (2007) finds evidence that real wages are considerably more procyclical during recessions than during periods of expansion in Portugal.

We follow this previous literature by allowing real income and wages to react differently. This asymmetric reaction can be captured by defining two dummy variables, $D_{1}$ and $D_{2}$, that take the value of 1 for positive or negative values of the output gap, respectively, and 0 otherwise. We then identify two asymmetric variables defined as $\left(y-y^{*}\right)_{t}^{+}=\left(y-y^{*}\right)_{t} \times D_{1}$ and $\left(y-y^{*}\right)_{t}^{-}=\left(y-y^{*}\right)_{t} \times D_{2}$, such that $\left(y-y^{*}\right)_{t}^{+}$captures the positive component of the output gap and, therefore, expansions and $\left(y-y^{*}\right)_{t}^{-}$captures the negative output gap. ${ }^{13}$ Replacing $\left(y-y^{*}\right)_{t}$ in

\footnotetext{
${ }^{13}$ In order to capture asymmetric effects during expansions and recessions, we rely on the output gap instead of the GDP growth. We do so in order to have enough variation to identify this split. Decomposing the GDP growth would result in most of the observations pertaining to economic expansions.
} 
Equation (4) by its decomposition into positive and negative components, we obtain the following asymmetric extension of the real wage/income cyclicality equation:

$$
\Delta \ln x_{i t}=\gamma_{2}+2 \gamma_{3} t+\gamma_{\left(y-y^{*}\right)^{+}}\left(y-y^{*}\right)_{t}^{+}+\gamma_{\left(y-y^{*}\right)^{-}}^{-}\left(y-y^{*}\right)_{t}^{-}+\beta^{\prime} X_{i t}+\left(\Delta \epsilon_{i t}+\Delta v_{t}\right)
$$

where all the variables were previously defined and $\left(y-y^{*}\right)_{t}^{+}+\left(y-y^{*}\right)_{t}^{-}=$ $\left(y-y^{*}\right)_{t}$ by definition. Note that $\left(y-y^{*}\right)_{t}^{+}\left(\right.$resp. $\left.\left(y-y^{*}\right)_{t}^{-}\right)$takes positive (negative) values for the positive (negative) component of the output gap, and 0 otherwise. Hence, the coefficient $\left(y-y^{*}\right)_{t}^{+}$in Equation (5) will be positive and significant if we expect wages or income to increase in periods of expansion. Equally, the coefficient $\left(y-y^{*}\right)_{t}^{-}$will also be positive if they decrease in periods of recession. We verify the reaction symmetry of the wage cyclicality can be verified with a Wald statistic testing the null hypothesis assumption that $\gamma_{\left(y-y^{*}\right)^{+}}=\gamma_{\left(y-y^{*}\right)^{-}}$. If the estimated coefficient for $\gamma_{\left(y-y^{*}\right)^{+}}$is higher than the estimated $\gamma_{\left(y-y^{*}\right)^{-}}$, then there is an asymmetry where expansions have higher impact on real wages than contractions. We estimate equation Eq. (5) for all the individuals in our sample and for each wage/income group.

Table 5 presents the results of the previous asymmetric specification. As seen, the Wald statistic testing the null hypothesis that the estimated rise of wages in booms is equal to the fall in recessions cannot be accepted at a $5 \%$ critical level. Interestingly, the results show that income is equally sensitive in expansions and recessions but recessions are particularly harmful for wages of top incomes. Note, however, that adding asymmetric effects over the business cycle does not change the acyclicality in the low income group.

What explains the acyclicality of individuals at the bottom end of the wage distribution? The literature emphasises job mobility as one reason for the different cyclicality among workers (e.g. Beaudry and DiNardo (1991)). However, Pavlopoulos, Fouarge, Muffels, and Vermunt (2007) conclude that the probability of job mobility does not appear to be different for the low and the high paid worker, with the driving forces of a job change being similar throughout the wage distribution.

We explore an alternative explanation by looking at the adjustments in the hours worked in each percentile of the income distribution. In particular, given the constraints to reduce wages - which are already low- of low wage workers, we analyse whether hours worked in the bottom income percentiles are more sensitive to the 
Table 5: Asymmetric cyclicality of real income and wages by income group

\begin{tabular}{|c|c|c|c|c|c|}
\hline Elasticity & $\begin{array}{c}\text { All } \\
\text { units }\end{array}$ & $\begin{array}{c}\text { Lowest } \\
10 \%\end{array}$ & $\begin{array}{c}\text { Lowest } \\
25 \%\end{array}$ & $\begin{array}{l}\text { Top } \\
25 \%\end{array}$ & $\begin{array}{l}\text { Top } \\
10 \%\end{array}$ \\
\hline \multicolumn{6}{|c|}{ INCOME } \\
\hline Expansions: $\gamma_{y-y *}^{+}$ & $\frac{(3.44)}{1.822}$ & $\begin{array}{l}0.985 \\
(0.71)\end{array}$ & $\begin{array}{l}1.091 \\
(0.64)\end{array}$ & $\begin{array}{l}\mathbf{3 . 2 6 7} \\
(5.61)\end{array}$ & $\underset{(1.87)}{\mathbf{2 . 6 8 7}}$ \\
\hline Recessions: $\gamma_{y-y *}^{-}$ & $\begin{array}{c}2.453 \\
(5.65)\end{array}$ & $\begin{array}{l}1.828 \\
(1.44)\end{array}$ & $\begin{array}{l}\mathbf{3 . 0 6 8} \\
(2.08)\end{array}$ & $\underset{(2.17)}{\mathbf{1 . 3 8 7}}$ & $\begin{array}{l}\mathbf{3 . 1 1 5} \\
(2.03)\end{array}$ \\
\hline Symmetry test & 0.297 & 0.545 & 0.340 & 0.011 & 0.841 \\
\hline \multicolumn{6}{|c|}{ WAGES } \\
\hline Expansions: $\gamma_{y-y *}^{+}$ & $\underset{(3.45)}{\mathbf{0 . 8 3 2}}$ & $\begin{array}{c}-0.899 \\
(-1.46)\end{array}$ & $\begin{array}{l}0.355 \\
(0.63)\end{array}$ & $\underset{(2.51)}{\mathbf{1 . 1 3 1}}$ & $\begin{array}{l}1.878 \\
(3.29)\end{array}$ \\
\hline Recessions: $\widehat{\gamma_{y-y *}^{-}}$ & $\begin{array}{l}\mathbf{2 . 1 9 1} \\
(11.02)\end{array}$ & $\begin{array}{l}-0.998 \\
(-1.18)\end{array}$ & $\begin{array}{c}\mathbf{1 . 7 9 7} \\
(3.20)\end{array}$ & $\begin{array}{l}2.502 \\
(5.88)\end{array}$ & $\underset{(5.04)}{\mathbf{3 . 3 4 6}}$ \\
\hline Symmetry test & 0.000 & 0.075 & 0.057 & 0.000 & 0.077 \\
\hline
\end{tabular}

Notes: (1) $\widehat{\gamma_{y}^{+}}$and $\widehat{\gamma_{y-y *}^{+}}$capture expansions according to the GDP growth and output gap, respectively; (1) $\widehat{\gamma_{y}^{-}}$and $\widehat{\gamma_{y-y *}^{-}}$capture recessions according to the GDP growth and output gap, respectively; (3) Symmetry test is the probability associated to the null hypothesis that the estimated coefficient is the same in expansions and recessions; (4) $t$-values in parenthesis; (5)

Significant coefficients at $10 \%$ significance level are indicated in bold.

cycle. The proposition is as follows. Individuals at the bottom percentile are close to the minimum wage. In contrast to high wages, this means that wages for this group cannot decrease -or decrease very little-in adverse conditions. Therefore, one could infer that adverse shocks eventuate in hours worked - or even job losses- rather than wage adjustments for individuals at the bottom of the distribution. Regarding income, the main source are pensions and benefits which are, as mentioned before, acyclic or counter-cyclical. This should explain, in part, the acyclicality observed for low income individuals.

There are a few studies supporting the proposition that working hours could be the adjustment mechanism in some cases. For instance, Clark and Summers (1981) and Kydland (1984) advance that low income households are the most affected by booms and recessions and that this greater sensitivity is due to the higher cyclicality of hours worked among this group. In contrast, Parker and Vissing-Jorgensen (2010) show that the cyclicality of hours only plays a minor role in the cyclicality of the top 1 percent. 
In order to investigate to what extent the adjustment to the cycle occurs through employment (hours), we regress the change in average weekly hours on the change in the GDP and the output gap for the different income groups. ${ }^{14}$ The cyclicality of hours is shown in the first panel in Table 6. As seen, the estimated cyclicality is non-significant for the whole sample as well as for the different percentiles. These results contradict some previous investigations that find a significant cyclicality of hours worked for all families but non-significant cyclicality for the top $1 \%$ income in the case of the United States (e.g. Parker and Vissing-Jorgensen (2010)). In contrast, Castro and Coen-Pirani (2008) find that the aggregate hours worked by individuals with a college degree -which are usually the highest salaried workershave become much more procyclical and volatile relative to aggregate output since the late $1980 \mathrm{~s}$.

We explore a further possibility by extending the sample to all the men, in the restricted age group, that have ever worked. If they do not work in the following periods, we impute 0 hours worked, constructing a balanced panel. This allows us to capture switches from employment to unemployment as well as reductions in the hours worked by workers who remain in the labour force. We refer to this sample as the extensive margin. The results, presented in Table 6 , show that the cyclicality for working hours is significant and positive for the whole sample and for the different wage groups. For instance, a $1 \%$ decrease in the GDP implies a decrease of about 0.3 hours worked per week, the cyclicality being more important for the lowest percentile (about 0.7 hours). Remember that there is a high percentage of these workers who have temporary contracts and are, therefore relatively easy to hire and fire. This finding may explain why wages are not cyclical for these workers. Indeed, according to the economic conditions, employers may react to the cycle by offering more or less working hours to their low income workers rather than higher or lower wages. We also observe acyclicality of hours worked for top-incomes (at least respect to the GDP growth), implying that adjustments for this group of individuals is mainly on the wage/income side rather than hours worked.

Together, our results for hours worked considering the intensive and the extensive labour margins indicate that negative economic conditions affect low wage workers mainly through transitions to unemployment, rather than hours worked or wages.

\footnotetext{
${ }^{14}$ In this case, we work only with income groups since we include individuals with zero worked hours and, therefore, zero wages, i.e. the extensive margin.
} 
These results are in line with Gregg, Machin, and Fernández-Salgado (2014) who show that unemployment levels are more important for low and middle earners. Note that we are treating the intensive and extensive margins differently when studying the cyclicality of income and hours worked. In the first case, joblessness is treated as a missing observation in the data and ignored. In the second case, joblessness is imputed as zero. As such, these workers disappear from our original sample, which explains why wages are not cyclic for the lowest percentiles. The acyclicality of income, in turn, is probably explained by the acyclicality of benefits and transfers, its main components.

\begin{tabular}{|c|c|c|c|c|c|}
\hline Elasticity & $\begin{array}{c}\text { All } \\
\text { units }\end{array}$ & $\begin{array}{c}\text { Lowest } \\
10 \%\end{array}$ & $\begin{array}{c}\text { Lowest } \\
25 \%\end{array}$ & $\begin{array}{l}\text { Top } \\
25 \%\end{array}$ & $\begin{array}{l}\text { Top } \\
10 \%\end{array}$ \\
\hline \multicolumn{6}{|c|}{ INTENSIVE MARGIN } \\
\hline$\widehat{\gamma_{y}}$ & $\begin{array}{c}0.022 \\
(0.95)\end{array}$ & $\begin{array}{c}-0.688 \\
(-1.04)\end{array}$ & $\begin{array}{c}0.076 \\
(0.38)\end{array}$ & $\begin{array}{c}0.013 \\
(0.40)\end{array}$ & $\begin{array}{l}0.013 \\
(0.23)\end{array}$ \\
\hline$\widehat{\gamma_{y-y} *}$ & $\begin{array}{c}0.009 \\
(0.24)\end{array}$ & $\begin{array}{l}0.171 \\
(0.16)\end{array}$ & $\begin{array}{l}0.206 \\
(0.61)\end{array}$ & $\frac{-0.011}{(-0.19)}$ & $\begin{array}{l}0.001 \\
(0.10)\end{array}$ \\
\hline \multicolumn{6}{|c|}{ EXTENSIVE MARGIN } \\
\hline$\widehat{\gamma_{y}}$ & $\underset{(5.81)}{\mathbf{0 . 3 1 9}}$ & $\underset{(3.81)}{\mathbf{0 . 7 1 6}}$ & $\underset{(2.54)}{\mathbf{0 . 5 0 1}}$ & $\begin{array}{c}0.068 \\
(0.80)\end{array}$ & $\begin{array}{l}0.032 \\
(0.23)\end{array}$ \\
\hline$\widehat{\gamma_{y-y} *}$ & $\underset{(14.39)}{\mathbf{1 . 3 4 1}}$ & $\underset{(2.95)}{\mathbf{1 . 1 6 3}}$ & $\underset{(3.60)}{\mathbf{1 . 1 9 5}}$ & $\begin{array}{c}\mathbf{1 . 0 8 8} \\
(7.52)\end{array}$ & $\underset{(4.08)}{\mathbf{0 . 7 7 9}}$ \\
\hline
\end{tabular}

Notes: (1) $\widehat{\gamma_{u}}$ is the estimated coefficient for cyclicality in Eq. (5); (2) t-values in parenthesis, (3) The extensive margin includes transition to unemployment (zero working hours); (4) Significant coefficients at $10 \%$ significance level are indicated in bold.) 


\section{Final remarks}

Micro studies in real wage cyclicality have shed light on several important questions in the macro-labour literature over the last 20 years or so (e.g. the role of composition bias). This paper presents additional evidence of this kind by analysing the differences in income and real wage cyclicality across income and wage groups. Using the British Household Panel Survey from 1991 to 2008, we conclude that the wages and income at the top of the income distribution are more procyclical than those at the bottom.

We also show that most income reacts symmetrically during recessions and expansions for the whole population and for the different groups. However, wages for high-income individuals are specially sensitive in recessions. In fact, this is the case for all wage groups excepts for those at the first percentile of the wage distribution.

In contrast, we present evidence that income and wages are acyclic for those at the bottom of the distribution. There are several possible explanations for this acyclicality. First, the large share of workers in the lowest income/wage groups that are paid close to the minimum wage explains in part the lack of real wage cyclicality amongst these groups. Second, there is also considerable cyclicality in hours worked when allowing for transitions to and from unemployment. Indeed, when considering the intensive margin, the hours worked are not cyclical. However, when the extensive margin is taken into account, changes in the GDP result in transitions to of from unemployment rather than decreases in real wages. The high proportion of low paid workers with temporary contracts probably means that the adjustment to the cycle is via employment for these workers. Finally, and in contrast to the case of rich individuals, the main sources of income for low income workers are benefits and transfers, which are basically counter-cyclic or acyclic.

Finally, our results tend to emphasise that changes in the cycle are not directly associated with high income and real wage cyclicality for low-income workers. However, an increase in inequality can be originated through higher unemployment among these workers. Indeed, if increases in unemployment result in higher poverty rates, then the cycle increases the share of poor individuals in the total population. This surely represents a source of income inequality in the long-term. 
6 Appendix 
Table 7: Robustness checks: Cyclicality of real income and wages by income and wage group for (A) Whole sample; (B) excluding individuals placed at the lowest and highest $1 \%$ in the income or wage distribution and $(\mathrm{C})$ excluding individuals in the extremes of the earnings life cycle

\begin{tabular}{|c|c|c|c|c|c|}
\hline Elasticity & $\begin{array}{c}\text { All } \\
\text { units }\end{array}$ & $\begin{array}{c}\text { Lowest } \\
10 \%\end{array}$ & $\begin{array}{c}\text { Lowest } \\
25 \%\end{array}$ & $\begin{array}{l}\text { Top } \\
25 \%\end{array}$ & $\begin{array}{l}\text { Top } \\
10 \%\end{array}$ \\
\hline \multicolumn{6}{|c|}{ (A) INCOME } \\
\hline$\widehat{\gamma_{y}}$ & $\underset{(4.02)}{\mathbf{0 . 2 4 5}}$ & $\begin{array}{l}0.534 \\
(1.01)\end{array}$ & $\begin{array}{l}1.675 \\
(1.13)\end{array}$ & $\underset{(4.33)}{1.720}$ & $\underset{(3.74)}{\mathbf{0 . 8 8 7}}$ \\
\hline$\widehat{\gamma y-y *}$ & $\begin{array}{c}\mathbf{1 . 5 1 1} \\
(3.98)\end{array}$ & $\begin{array}{l}1.977 \\
(0.78)\end{array}$ & $\begin{array}{c}2.508 \\
(1.01)\end{array}$ & $\begin{array}{c}\mathbf{2 . 2 9 4} \\
(4.34)\end{array}$ & $\begin{array}{c}\mathbf{2 . 8 9 5} \\
(3.25)\end{array}$ \\
\hline \multicolumn{6}{|c|}{ (A) WAGES } \\
\hline$\widehat{\gamma_{y}}$ & $\underset{(4.87)}{\mathbf{0 . 5 6 5}}$ & $\begin{array}{c}\mathbf{- 0 . 4 0 7} \\
(-1.53)\end{array}$ & $\underset{(0.29)}{\mathbf{0 . 0 7 2}}$ & $\begin{array}{c}\mathbf{0 . 6 8 1} \\
(3.01)\end{array}$ & $\underset{(2.85)}{\mathbf{0 . 8 8 9}}$ \\
\hline$\widehat{\sqrt{y-y} *}$ & $\begin{array}{c}1.441 \\
(7.98)\end{array}$ & $\begin{array}{l}\mathbf{0 . 0 9 0} \\
(-0.16)\end{array}$ & $\begin{array}{c}\mathbf{0 . 6 1 4} \\
(1.39)\end{array}$ & $\begin{array}{c}\mathbf{1 . 8 2 3} \\
(4.84)\end{array}$ & $\begin{array}{c}\mathbf{2 . 0 6 5} \\
(3.43)\end{array}$ \\
\hline
\end{tabular}

\begin{tabular}{|c|c|c|c|c|c|}
\hline \multicolumn{6}{|c|}{ (B) INCOME } \\
\hline$\widehat{\gamma_{y}}$ & $\underset{(3.75)}{\mathbf{0 . 5 2 5}}$ & $\begin{array}{c}-0.434 \\
(-1.41)\end{array}$ & $\begin{array}{c}-0.647 \\
(-0.57)\end{array}$ & $\underset{(3.86)}{\mathbf{0 . 6 3 6}}$ & $\underset{(3.88)}{\mathbf{0 . 5 1 6}}$ \\
\hline$\widehat{\gamma y-y *}$ & $\underset{(4.41)}{\mathbf{2 . 1 0 7}}$ & $\begin{array}{c}-0.930 \\
(-1.60)\end{array}$ & $\begin{array}{c}-0.367 \\
(-0.19)\end{array}$ & $\underset{(4.62)}{\mathbf{2 . 5 3 7 7}}$ & $\begin{array}{c}3.022 \\
(3.16)\end{array}$ \\
\hline \multicolumn{6}{|c|}{ (B) WAGES } \\
\hline$\widehat{\gamma_{y}}$ & $\underset{(5.74)}{\mathbf{0 . 6 4 2}}$ & $\begin{array}{c}-0.379 \\
(-1.29)\end{array}$ & $\begin{array}{c}0.213 \\
(0.85)\end{array}$ & $\underset{(4.21)}{\mathbf{0 . 8 0 4}}$ & $\underset{(4.22)}{\mathbf{1 . 0 1 3}}$ \\
\hline$\widehat{\gamma y-y *}$ & $\underset{(8.35)}{\mathbf{1 . 4 6 6}}$ & $\underset{(0.21)}{\mathbf{0 . 1 1 7}}$ & $\underset{(1.59)}{\mathbf{0 . 6 7 0}}$ & $\begin{array}{c}\mathbf{1 . 7 3 5} \\
(5.09)\end{array}$ & $\begin{array}{c}\mathbf{2 . 1 6 8} \\
(4.78)\end{array}$ \\
\hline \multicolumn{6}{|c|}{ (C) INCOME } \\
\hline$\widehat{\gamma_{y}}$ & $\underset{(4.16)}{\mathbf{0 . 4 2 0}}$ & $\begin{array}{l}-1.46 \\
(-0.213)\end{array}$ & $\begin{array}{c}-0.634 \\
(-1.05)\end{array}$ & $\underset{(3.78)}{\mathbf{0 . 6 8 1}}$ & $\underset{(4.89)}{\mathbf{0 . 9 2 5}}$ \\
\hline$\widehat{\gamma_{y-y} *}$ & $\begin{array}{c}\mathbf{1 . 8 5 4} \\
5.63)\end{array}$ & $\begin{array}{c}-2.655 \\
(-0.98)\end{array}$ & $\begin{array}{c}0.289 \\
(-0.26)\end{array}$ & $\underset{(4.26)}{\mathbf{2 . 2 0 0}}$ & $\begin{array}{c}\mathbf{2 . 4 8 5} \\
(4.84)\end{array}$ \\
\hline \multicolumn{6}{|c|}{ (C) WAGES } \\
\hline$\widehat{\gamma_{y}}$ & $\underset{(5.04)}{\mathbf{0 . 5 9 9}}$ & $\frac{-\mathbf{0 . 3 3 0}}{(-1.12)}$ & $\underset{(1.25)}{\mathbf{0 . 3 2 0}}$ & $\underset{(2.85)}{\mathbf{0 . 6 8 0}}$ & $\underset{(2.43)}{\mathbf{0 . 7 9 6}}$ \\
\hline$\widehat{\gamma y-y *}$ & $\underset{(8.43)}{\mathbf{1 . 5 3 7}}$ & $\begin{array}{l}0.384 \\
(0.08)\end{array}$ & $\begin{array}{l}0.982 \\
(2.20)\end{array}$ & $\underset{(4.82)}{\mathbf{1 . 9 2 9}}$ & $\begin{array}{c}\mathbf{1 . 9 0 8} \\
(3.01)\end{array}$ \\
\hline
\end{tabular}

Notes: (1) $\widehat{\gamma_{y}}$ and $\widehat{\overline{\gamma_{y-y} *} \text { are the estimated coefficient for cyclicality according to G }}$ DP growth and output gap, respectively; (2) $t$-values in parenthesis; (3) Significant coefficients at $10 \%$ significance level are indicated in bold. 


\section{References}

Beaudry, P., and J. Dinardo (1991): "The Effect of Implicit Contracts on the Movement of Wages over the Business Cycle: Evidence from Micro Data," Journal of Political Economy, 99(4), 665-88.

Bils, M. J. (1985): "Real Wages over the Business Cycle: Evidence from Panel Data," Journal of Political Economy, 93(4), 666-89.

Castro, R., and D. Coen-Pirani (2008): "Why have aggregate skilled hours become so cyclical since the mid-1980s?," International Economic Review, 49(1), $135-185$.

Clark, K. B., and L. H. Summers (1981): "Demographic Differences in Cyclical Employment Variation," Journal of Human Resources, 16(1), 61-79.

Devereux, P. J., And R. A. Hart (2006): "Real wage cyclicality of job stayers, within-company job movers, and between-company job movers," Industrial and Labor Relations Review, 60(1), 105-119.

$\Omega$ Égert

Égert, B. (2010): "Fiscal Policy Reaction to the Cycle in the OECD: Pro- or Counter-cyclical?," OECD Economics Department Working Papers 763, OECD Publishing.

GregG, P., S. Machin, and M. Fernández-Salgado (2014): "Real Wages and Unemployment in the Big Squeeze," Economic Journal, 0(576), 408-432.

Hart, R. A. (2006): "Worker-Job Matches, Job Mobility and Real Wage Cyclicality," Economica, 73(290), 287-298.

Hines, J., H. Hoynes, And A. Krueger (2002): The Roaring Nineties: Can Full Employment Be Sustained?chap. Another Look at Whether a Rising Tide Lifts All Boats, pp. 493-537. New York, NY : Century Foundation Press.

Kydland, F. E. (1984): "Labor-force heterogeneity and the business cycle," Carnegie-Rochester Conference Series on Public Policy, 21(1), 173-208.

Martins, P. S. (2007): "Heterogeneity in Real Wage Cyclicality," Scottish Journal of Political Economy, 54(5), 684-698. 
Mitchell, M., M. Wallace, and J. Warner (1985): "Real Wages over the Business Cycle: Some Further Evidence," Southern Economic Journal, 51, 11621173.

Parker, J. A., And A. Vissing-Jorgensen (2010): "The Increase in Income Cyclicality of High-Income Households and Its Relation to the Rise in Top Income Shares," Brookings Papers on Economic Activity, 41(2 (Fall)), 1-70.

Pavlopoulos, D., D. Fouarge, R. Muffels, and J. K. Vermunt (2007): "Who benefits from a job change: The dwarfs or the giants?," IRISS Working Paper Series 2007-16, IRISS at CEPS/INSTEAD.

Piketty, T., And E. SAEz (2012): "Top Incomes and the Great Recession: Recent Evolutions and Policy Implications," IMF, 13th Jacques Polak annual research conference.

RABE, B. (2011): "Dual-earner migration. Earnings gains, employment and selfselection," Journal of Population Economics, 24(2), 477-497.

Shin, D., And K. Shin (2008): "Why Are The Wages Of Job Stayers Procyclical?," Macroeconomic Dynamics, 12(01), 1-21.

Shin, D., And G. Solon (2007): "New Evidence On Real Wage Cyclicality Within Employer-Employee Matches," Scottish Journal of Political Economy, 54(5), 648660 .

Solon, G., R. Barsky, and J. A. PArker (1994): "Measuring the Cyclicality of Real Wages: How Important Is Composition Bias?," The Quarterly Journal of Economics, 109(1), 1-25.

Solon, G., W. Whatley, and A. H. Stevens (1997): "Wage Changes and Intrafirm Job Mobility over the Business Cycle: Two Case Studies," Industrial and Labor Relations Review, 50(3), pp. 402-415.

Stewart, M. B., and J. K. Swaffield (2002): "Using the BHPS Wave 9 Additional Questions to Evaluate the Impact of the National Minimum Wage," Oxford Bulletin of Economics and Statistics, 64(0), 633-52.

Swanson, E. T. (2007): "Real wage cyclicality in the PSID," Discussion paper. 